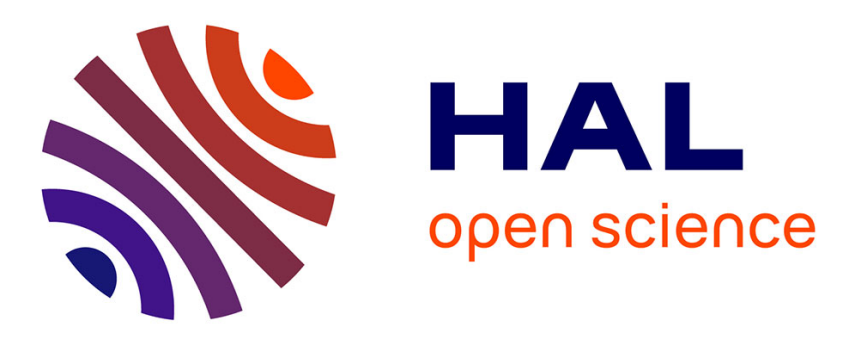

\title{
Interhypothalamic adhesion and multiple cerebral abnormalities in a 2-year-old boy.
}

\author{
Antoine Loubet, Cyril Dargazanli, Charles Joris Roux, Francois Rivier, \\ Nicolas Menjot de Champfleur, Nicolas Leboucq
}

\section{To cite this version:}

Antoine Loubet, Cyril Dargazanli, Charles Joris Roux, Francois Rivier, Nicolas Menjot de Champfleur, et al.. Interhypothalamic adhesion and multiple cerebral abnormalities in a 2-year-old boy.. Journal de Neuroradiologie / Journal of Neuroradiology, 2017, pp.63-64. 10.1016/j.neurad.2016.09.001 . hal01727780

\author{
HAL Id: hal-01727780 \\ https://hal.science/hal-01727780
}

Submitted on 17 Dec 2019

HAL is a multi-disciplinary open access archive for the deposit and dissemination of scientific research documents, whether they are published or not. The documents may come from teaching and research institutions in France or abroad, or from public or private research centers.
L'archive ouverte pluridisciplinaire HAL, est destinée au dépôt et à la diffusion de documents scientifiques de niveau recherche, publiés ou non, émanant des établissements d'enseignement et de recherche français ou étrangers, des laboratoires publics ou privés. 


\section{Interhypothalamic adhesion and multiple cerebral abnormalities in a 2-year-old boy}

\section{Introduction}

Interhypothalamic adhesion (IHA) is a band of tissue spanning the anterior recess of the third ventricle, linear in the transverse and frontal planes. Recently described, in 2008 [1] in a patient with a Chiari type II malformation, IHA is commonly associated with multiple congenital anomalies [2] particularly midline disorders but can also be isolated. IHA is related with hypothalamo-pituitary dysfunctions and seizures in most of patient, but asymptomatic patients have been reported [3]. Here, we present a case of IHA associated with corpus callosum agenesis (CCA).

\section{Description of the case}

A two-year-old boy was referred to our institution for complete CCA. He was a preterm infant, born at 32 weeks of gestation during which complete CCA had been discovered on cranial ultrasonography at 8 days of life. The first brain MRI at two months confirmed the CCA but also showed gray matter nodular heterotopias along the two lateral ventricles. He recently presented two hyperthermic seizure episodes. A second brain MRI was performed (Fig. 1) showing the CCA and nodular heterotopia focuses. Furthermore, an abnormal thin band of tissue was observed in the medial interhypothalamic region, above the tuber cinereum, across the third ventricle, appearing iso-intense to gray matter.
The hypothalamo-hypophyseal axis was normal as well as the anterior and hippocampal commissures. A right optic nerve atrophy was also observed.

\section{Discussion}

Since it was described in 2008, all reports of IHA have been ambiguous. Hypothalamic lesions (mainly hamartoma, glioma and dysgenesis) are often responsible for seizures or central endocrine dysfunction. In a recent publication, rather than a migration, IHA is considered as an accessory hypothalamic tissue or a failed apoptosis [3].

Similar to our case, IHA has been described in association with gray matter heterotopia [2,3]. It has also been associated with atrophy of the optic pathways [3] as seen in our patient.

In association with IHA, Ahmed et al. [3] reported a case of hypogenesis of the splenium of the corpus callosum, but the present report is, to our knowledge, the first observation of a complete CCA. Other midline (cleft palate [4], septo-optic dysplasia) or extra-midline abnormalities (hippocampal under-rotation, olfactory hypoplasia, hypoplastic falx, white matter lesions [3]) have been described.

This case highlights that IHA is usually observed in the context of a polymalformative syndrome. A genetic origin of midline abnormalities associated with IHA is suspected, thus not yet identified. IHA has two main differential diagnoses: hypothalamic hamartoma and hypothalamic glioma. IHA is a recently described anatomical entity whose pathological significance is still debated. It can be isolated and asymptomatic but also included in a wider polymalformative syndrome [5]. 

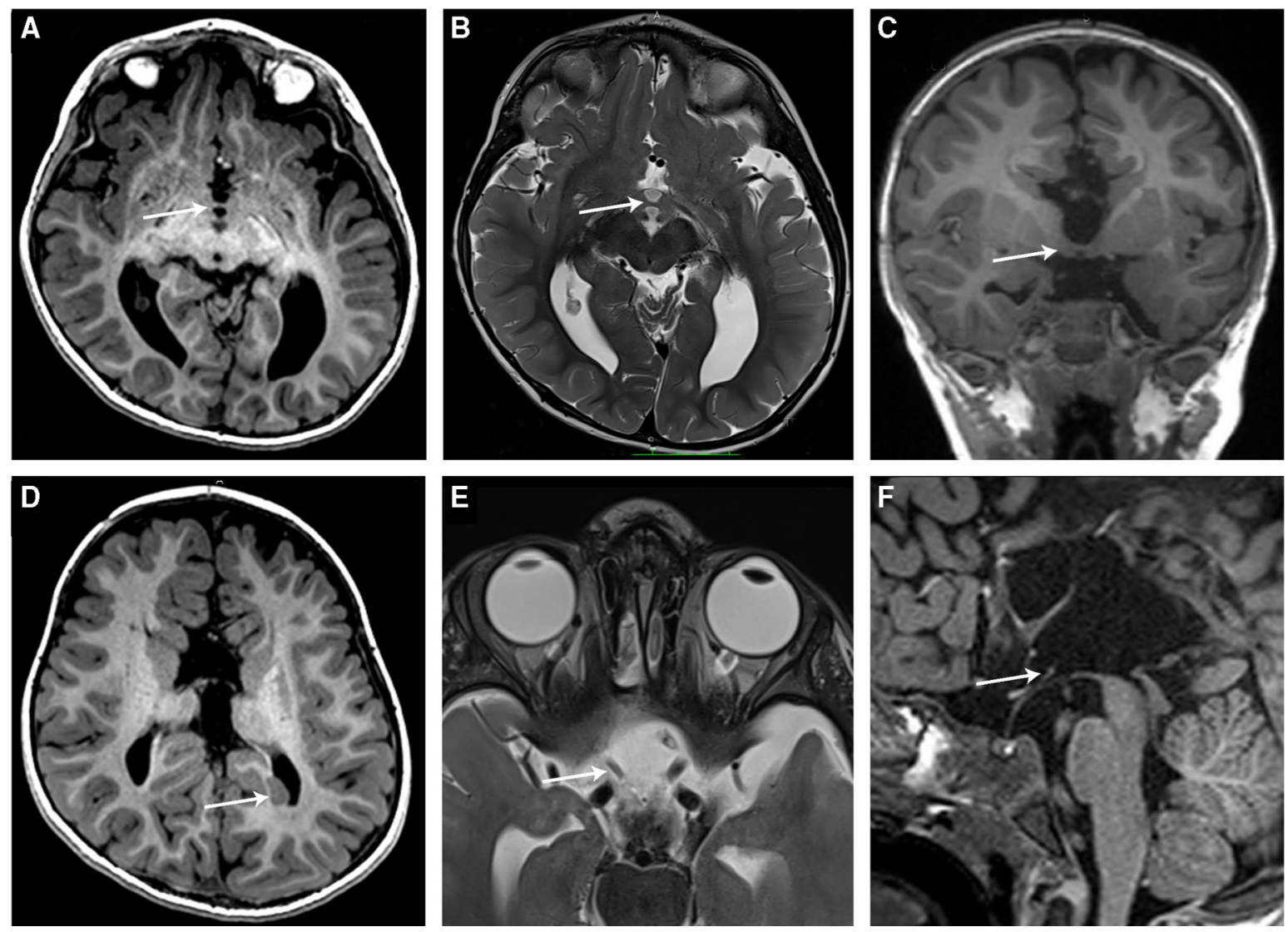

Figure 1 On T1- and T2-weighted images, interhypothalamic adhesion appears as a band of tissue, iso-intense to gray matter, linear in transverse ( $A$ and $B$, arrow) and frontal planes ( $C$, arrow); and nodular in the sagittal plane ( $F$, arrow). Left periventricular heterotopia is visible on transverse T1-weighted images $(\mathrm{D}$, arrow) and a right optic nerve atrophy is observed on T2-weighted images $(E$, arrow). Corpus callosum agenesis is seen on the sagittal plane in the T1-weighted image $(F)$. Note the normal hypothalamohypophyseal axis.

\section{Disclosure of interest}

The authors declare that they have no competing interest.

\section{References}

[1] Miller E, Widjaja E, Blaser S, et al. The old and the new: supratentorial MR findings in Chiari II malformation. Childs Nerv Syst 2008;24:563-75.

[2] Whitehead MT, Vezina G. Interhypothalamic adhesion: a series of 13 cases. Am J Neuroradiol 2014;35:2002-6.

[3] Ahmed FN, Stence NV, Mirsky DM. Asymptomatic interhypothalamic adhesions in children. Am J Neuroradiol 2016;37(4):726-9.

[4] Whitehead MT, Angel JD. Interhypothalamic adhesion in a 9 month-old male with cleft palate. Case Rep Radiol 2013;2013:197415.

[5] Perucca G, Leboucq N, Roubertie A, et al. Role of neuroimaging in the diagnosis of hereditary cerebellar ataxias in childhood. J Neuroradiol 2016;43(3):176-85.

Antoine Loubet ${ }^{\mathrm{a}}$ Cyril Dargazanlia Charles Joris Roux ${ }^{a, b}$

François Rivier ${ }^{b}$ Nicolas Menjot de Champfleur ${ }^{\mathrm{a}, \mathrm{c}, \mathrm{d}, \mathrm{e}, \mathrm{f}}$ Nicolas Leboucq ${ }^{\mathrm{a}, \mathrm{g}, *}$ a Département de Neuroradiologie, Hôpital Gui-de-Chauliac, CHRU de Montpellier, 34000 Montpellier, France

${ }^{\mathrm{b}}$ Département de Neuropédiatrie, Hôpital Gui-de-Chauliac, CHRU de Montpellier, 34000 Montpellier, France

'Département d'Imagerie Médicale, CHU Caremeau, 34000 Nîmes, France

d Institut d'Imagerie Fonctionnelle Humaine (I2FH), Hôpital Gui-de-Chauliac, CHRU de Montpellier, 34000 Montpellier, France

e Institut de Neurosciences de Montpellier, Inserm U1051, Hôpital Saint-Eloi, 34000 Montpellier, France

' Laboratoire Charles-Coulomb, CNRS UMR 5221, Université de Montpellier, 34000 Montpellier, France

s Département d'Imagerie Pédiatrique, Hôpital Arnaud-de-Villeneuve, $\mathrm{CHU}$ de Montpellier, 34000 Montpellier, France

* Corresponding author at: Department of Neuroradiology, University Hospital Center, Gui-de-Chauliac Hospital, 80, avenue Augustin-Fliche, 34295 Montpellier cedex 5, France. Tel.: +33 46733 75; mobile: +336146734 13; fax: +33467336838.

E-mail address: leboucq.nicolas@neuf.fr (N. Leboucq) 